\title{
THE EASE OF IGNITION OF 13 LANDSCAPE MULCHES
}

\section{by Larry G. Steward, ${ }^{1}$ T. Davis Sydnor, ${ }^{2}$ and Bert Bishop ${ }^{3}$}

\begin{abstract}
The ease of ignition of 13 commonly used landscape mulches was evaluated. Mulches have different ignition potentials based on several factors, including the length of exposure to heat and to the ignition source. Some materials ignited more frequently when exposed to a lit propane torch for 15 seconds. The most to least commonly ignited materials were ground rubber, pine straw, oat straw, shredded hardwood bark, shredded cypress bark, recycled pallets, 2.5 to $5 \mathrm{~cm}$ pine bark nuggets, 1.3 to $2.5 \mathrm{~cm}$ pine bark nuggets, shredded pine bark, cocoa shells, composted yard waste, bluegrass sod, and brick chips. Not all organic mulches readily ignited, nor were inorganic mulches uniformly ignition resistant. The results of this research show that there are definite differences in the ease of ignition between commonly used mulches. The results demonstrate that landscapers do not have to resort to using inorganic materials such as brick chips and gravel for ignition-resistant mulches. Under high-temperature ignition, one inorganic material, ground rubber was ignited consistently and was difficult to extinguish. Conversely, there are organic materials that are unlikely to ignite. These also are maintenance practices that will prevent or reduce ignition of these mulches.
\end{abstract}

Key Words. Mulch; fire; ignition; combustion; pine bark; hardwood bark; straw; ground rubber.

Mulches are commonly applied after shrubs and ground covers are planted in the landscape. Mulches are chosen for a variety of aesthetic and economic reasons including eye appeal, color, availability, lawn maintenance equipment protection, and price. Mulches are also chosen for a variety of cultural reasons including reduction in soil moisture evaporation rates, nutrient content, reduction in weed competition, moderation of soil temperatures, and dust abatement (Appleton and French 1995; Rose and Smith 1996).

Many commercial and public facilities no longer permit smoking inside as a result of today's laws and policies. Cigarette and cigar smokers often discard lit smoking material into the landscaped areas as they enter a building, thus causing the potential for mulch ignition. As people move from smoking areas outside the building to areas within, discarded cigarettes smolder and may set the mulch on fire. Mulch fires, in turn, can place frame construction buildings at risk (Appleton et al. 1998; Dennis 1999; Cohen 2000).

The risk of a mulch fire is, perhaps, more common than one might expect. The Ohio State University Agricultural Technical Institute campus in Wooster, Ohio, U.S., had an incident in fall 2000 where smoldering mulch betrayed a subsurface mulch fire (Garrod 2000). In Columbus, Ohio, a mulch fire was credited with severely damaging a building (Narciso 1997). Scioto Dublin High School in Dublin, Ohio, was closed as a result of a mulch fire that contaminated the air-handling system in the building (Sternberg 1997). An improperly discarded cigarette ignited the landscape mulch and then spread into the crawl space beneath the structure, damaging a Brookhaven National Laboratory structure (Levesque 2001). Problems such as the above have become enough of a nuisance at The University of Maryland that their Environmental and Safety Department developed a mulch fire standard operating procedure (Mulch Fire Standard 2002).

\section{MATERIALS AND METHODS}

Thirteen mulches commonly used as landscape mulches (Sydnor 1994; Rose and Smith 1996; Williams 1996; Relf 1997) were chosen for evaluation for their ease of ignition under natural field conditions. They included the following organic materials: shredded pine bark, shredded hardwood, shredded cypress, composted yard waste, 1.3 to $2.5 \mathrm{~cm}$ pine bark nuggets, 2.5 to $5 \mathrm{~cm}$ pine bark nuggets, pine straw (needles), recycled wooden pallets, cocoa shells, oat straw, and mixed grass sod. Inorganic materials included brick chips and ground rubber-tire mulches. The null hypothesis assumed that materials were equally easily ignited.

Aluminum edging strips were used to divide the test areas into circular areas of $0.84 \mathrm{~m}^{2}$ each. The aluminum edging strips were used to prevent mulch from igniting adjacent blocks and contaminating adjacent areas with other mulching materials. Additionally, turf was employed to further separate the test areas. Mulch depth for each sample was approximately $10 \mathrm{~cm}$ (Sydnor 1994; Appleton and French 1995). Natural conditions were utilized to simulate landscape conditions and to identify conditions for future study.

The mulches were not treated with any fireproofing material (Hickman 1996). The purpose of this test was to demonstrate what could happen in the environment found in typical landscapes.

Mulches were applied to the test plots on October 19, 2000 , and allowed to settle for 2 weeks prior to initiating ignition tests. The mulch materials were subjected to ignition by cigarettes, matches, and a propane torch. For the cigarette ignition tests, student volunteers were asked to ignite and then discard three lit filter cigarettes on the surface of each of the four replicates of each mulch sample. The cigarettes and mulches were monitored for 20 minutes to determine if the 
mulch material ignited. The period of time was measured in seconds from application of the burning cigarettes to ignition of the mulching material. Flames in excess of $15 \mathrm{~cm}$ high were noted and then extinguished. The cigarette ignition trial was repeated. The first test was conducted on November 2, 2000, 14 days after the mulch was applied, and the second test was conducted on July 27, 2001, to determine if there was any change in ease of ignition due to natural weathering. Weather conditions on November 2 , 2000 , were relatively calm (winds less than $8 \mathrm{~km}$ per hour) with temperatures near $10^{\circ} \mathrm{C}$ after a high of $20^{\circ} \mathrm{C}$ and a low of $1.1^{\circ} \mathrm{C}$. There had been one day since measurable rain $(0.254 \mathrm{~mm})$, and the average relative humidity was $68 \%$ with a high of $98 \%$ and a low of $26 \%$ (Weather Records 2002).

The second test was done on July 27, 2001. Weather conditions on that day were air temperatures of $18.3^{\circ} \mathrm{C}$ at time of the test after a high of $27.2^{\circ} \mathrm{C}$ and a low of $13.3^{\circ} \mathrm{C}$. Wind was relatively calm. The relative humidity averaged $54 \%$ with a high of $78 \%$ and a low of $26 \%$. It had been one day since measurable amounts of rain $(3.556 \mathrm{~mm})$. (Weather Records 2002)

Match ignition tests were conducted on April 26, 2001. Three wooden matches were lit and thrown onto the surfaces of each of the four replicates of each. The time from ignition to an active flame in the mulch or when the matches burned out was recorded. The conditions at the time (mid-day) were clear, with a temperature of $12.8^{\circ} \mathrm{C}$ and a light breeze $(8 \mathrm{~km}$ per hour) gusting to $11.3 \mathrm{~km}$ per hour. It had been 2 days since any measurable rainfall $(0.254 \mathrm{~mm})$. Relative humidity was an average of $58 \%$, having been as high as $100 \%$ and as low as 20\% (Weather Records 2002).

The propane torch ignition tests of the mulches were done on November 2, 2001. The flame of the propane torch was in contact with the surface of each of the four replicates of the mulch samples for 15 seconds. The torch flame was then removed, and the time from removal of torch flame until flames or coals were extinguished was recorded up to a maximum of 60 seconds. Residual flames or embers were mechanically extinguished after 60 seconds. Ease of ignition following the torch ignition tests was rated on a scale from 1 to 7 as follows:

$1=$ no flame or embers at 15 seconds

2 = flame at 15 seconds but no embers at 30 seconds

3 = flame at 15 seconds and embers at 30 seconds, but no embers at 60 seconds

4 = flame at 30 seconds, but no embers at 60 seconds

5 = flame at 15 seconds and embers at 60 seconds, with embers extinguished

6 = flame at 30 seconds and embers at 60 seconds, with embers extinguished

7 = flame at 60 seconds with flames and embers extinguished

The environmental conditions that afternoon were clear, $10^{\circ} \mathrm{C}$, with an average relative humidity of $83 \%$ after a high of $100 \%$ and a low of $60 \%$. It had been a week since a measurable amount of rain $(0.254 \mathrm{~mm})$ had fallen (Weather Records 2002).

Originally, four replicates of the 13 mulches were arranged in a randomized block pattern. There was no blocking effect in any of the tests; thus, the data were analyzed as a completely random design. Data from the torch ignition tests were evaluated using analysis of variance with mean separations using the least significant differences.

Ignition following the cigarette ignition and match ignition tests was rated in a binary fashion as either igniting or not and evaluated using logistic regression tests. Differences were determined using Fisher's Exact Test.

\section{RESULTS AND DISCUSSION Cigarette Trials}

Based on the two cigarette trials, cigarettes discarded on the mulch surfaces were able to ignite composted yard wastes and ground recycled pallets more often than ground rubber, pine straw, shredded hardwood, 2.5 to $5 \mathrm{~cm}$ pine bark nuggets, cocoa shells, brick chip mulches, and bluegrass sod (Table 1).

Oat straw, shredded cypress bark, 1.3 to $2.5 \mathrm{~cm}$ pine bark nuggets, and shredded pine bark ignited infrequently enough that they were not statistically different than those that never ignited (Table 1). Interestingly, oat straw ignited only during the first trial, while shredded cypress bark, recycled yard wastes, shredded pine bark, and ground recycled pallets ignited only after being in the landscape for 6 months (data not shown). Weathering of the materials appears to decrease the ease of ignition of oat straw while increasing the ignitability of the other four mulches.

Table 1. The number of times that specific mulch types ignited after three cigarettes were discarded on the surface of the mulch is given. Each trial was conducted twice on each of the four replicates.

\begin{tabular}{ll}
\hline Mulching material & Times ignition occurred ${ }^{z}$ \\
\hline Ground recycled pallets & $4^{y}$ \\
Composted yard waste & $4^{y}$ \\
Shredded pine bark & 3 \\
Oat straw & 2 \\
Shredded cypress bark & 2 \\
Pine bark nuggets 1.3 to $2.5 \mathrm{~cm}$ & 1 \\
Decorative ground rubber & 0 \\
Pine straw (needles) & 0 \\
Shredded hardwood bark & 0 \\
Pine bark nuggets 2.5 to $5 \mathrm{~cm}$ & 0 \\
Cocoa shells & 0 \\
Bluegrass sod & 0 \\
Brick chips & 0
\end{tabular}

${ }^{2}$ Ignition of each mulch was attempted eight times ( 2 trials $* 4$ replicates) using lighted cigarettes.

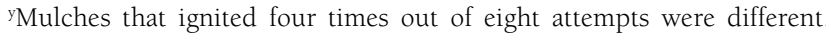
at the 0.05 level of significance, from mulches that never ignited using the Fisher's Exact Test. Logistic regression showed no differences between mulches that sometimes ignited. 


\section{Match Tests}

Mulches were also ignited by matches, but the match ignition test was not repeated. So few replicates of the various types of mulch ignited this way that statistical differences were not identified. The match test was done after the mulches had been in place for 6 months. Although not statistically significant, some replicates of pine straw, oat straw, and the decorative ground rubber sometimes ignited using matches (data not shown).

\section{Torch Tests}

Sod and brick chips did not ignite and did not ignite under any of the conditions tested. This was as expected. The torch killed grass foliage, but the live tissue did not allow the flame to propagate itself after the torch flame was removed. Brick is an inorganic material. Only debris such as grass clippings on the brick mulch burned, but it was not in sufficient quantity to allow the flame to propagate after the torch was removed.

One of the most ignition resistant of the organic mulches was cocoa shells. Cocoa shells were statistically more fire resistant ( $\alpha=0.05$ ) than decorative ground rubber, pine needles, oat straw, shredded hardwood bark, and shredded cypress bark (Table 2).

Composted yard waste responded interestingly and resisted ignition using the propane torch for 15 seconds (Table 2). Cigarettes, on the other hand, ignited composted yard wastes as readily as any material (Table 1 ). Composted yard waste smoldered when ignited by cigarettes but did not burst into flame. The longer time that a cigarette smolders on the composted yard waste surface may well be the difference. Smoldering mulch (duff) may be as dangerous as flaming mulch to the surrounding plants (Dickinson and Johnson 2001) and introduces the impact of soil heating that is not seen when the duff layer does not smolder (Miyanishi 2001). The smoldering mulch might escape detection and be allowed to burn longer. Furthermore, the longer time that smoldering mulch would be in contact with the bark of a tree or shrub might result in greater cambial heating and thus more extensive cambial injury.

Hardwood and pine bark mulch products were generally intermediate in tolerance to torch ignition. While not always statistically significant, pine bark mulch products were more torch resistant than hardwood products (Table 2). While hardwood mulches caught fire, the flames and embers usually died out without having to be put out. Generally, the torch ignitions failed to propagate; ease of ignition ratings were below four, with the exception of shredded hardwood bark (Table 2).

Pine straw and oat straw usually had to be put out by the investigators, as shown by their ease of ignition ratings of five or higher (Table 2). These fires propagated following torch ignition; therefore, these mulches would be expected to be a significant concern in the landscape.

Decorative ground rubber ignited each time it was exposed to the propane torch and produced spreading flames in 60 seconds. Ground rubber always had to be
Table 2. Propane torch flammability ratings of 13 mulching materials commonly used in landscape maintenance operations. Ease of ignition ratings is the average of two trials with four replicates in each trial.

\begin{tabular}{ll} 
Mulching material & Times \\
\hline Decorative ground rubber & 7.00 \\
Pine straw (needles) & 6.88 \\
Oat straw & 5.00 \\
Shredded hardwood bark & 4.13 \\
Shredded cypress bark & 4.00 \\
Ground recycled pallets & 3.75 \\
Pine bark nuggets 2.5 to $5 \mathrm{~cm}$ & 3.25 \\
Pine bark nuggets 1.3 to $2.5 \mathrm{~cm}$ & 3.13 \\
Shredded pine bark & 2.88 \\
Cocoa shells & 2.63 \\
Composted yard waste & 2.13 \\
Bluegrass sod & 2.13 \\
Brick chips & 1.13 \\
LSD & 1.19
\end{tabular}

${ }^{2}$ Ease of ignition ratings:

$1=$ No flame at 15 seconds. No embers at 15 seconds .

2 = Flame at 15 seconds. No embers at 30 seconds.

3 = Flame at 15 seconds. Embers at 30 seconds. No embers at 60 seconds.

$4=$ Flame at 30 seconds. No embers at 60 seconds.

$5=$ Flame at 15 seconds. Embers at 60 seconds. Extinguished.

6 = Flame at 30 seconds. Embers at 60 seconds. Extinguished.

$7=$ Flame at 60 seconds. Extinguished.

extinguished by the investigators (Table 2). The flames often spread rapidly and were extinguished with difficulty. Decorative ground rubber is sometimes recommended for use in playgrounds to cushion falls, but in our judgment is far too easily ignited for this use. The article "Playground Fires Tied to Cigarettes" reaffirms our concern (Playground Fires 1997).

The mulches that were the most fire resistant under all methods of ignition were cocoa shells, sod, 2.5 to $5 \mathrm{~cm}$ pine bark nuggets, shredded hardwood, and brick chips under the test parameters. These mulches might serve as standards for further testing.

One of the purposes of this study was to employ natural landscape conditions and to identify areas for further study. Some of the mulches were ignited by cigarettes that smoldered on the mulch surfaces for several minutes but not by 15 seconds of exposure to the torch, even though the torch ignition temperature was presumably much higher. This suggests that the length of time the mulch is subjected to the ignition source as well as its actual temperature will affect mulch ignition. Moisture content of the mulches is another area deserving of study. Weathering affected mulches differently in this study, with some mulches increasing in ignitability and others decreasing. This finding suggests additional investigation of mulches not evaluated in this study. Finally, the ignition point of various mulches should be defined under standardized test conditions. 


\section{LITERATURE CITED}

Appleton, B.L., and S. French 1995. Tree and Shrub Planting Guidelines. Virginia Cooperative Extension Publication 430-295. 2 pp.

Appleton, B.L., C.L. Frenzel, J.B. Hillegass, R.E. Lyons, and L.G. Steward. 1998. Virginia Firescapes. Virginia Cooperative Extension Publication 430-300. 11 pp.

Cohen, J.D. 2000. Preventing disaster: Home ignitability in the wildland-urban interface. J. For. 98(3):15-21.

Dennis, F.C. 1999. Fire-Resistant Landscaping, Colorado State University Cooperative Extension Bulletin 6.303.

Dickinson, M.B., and E.A. Johnson. 2001. Fire effects on trees, pp 477-526. In Johnson, E.A., and K. Miyanishi (Eds.). Forest Fires: Behavior and Ecological Effects. Academic Press, New York, NY.

Garrod, B. 2000. Personal communication. Landscape Supervisor, The Ohio State University Agricultural Technical Institute, Wooster $\mathrm{OH}$.

Hickman, G.W., and E. Perry. 1996. Using ammonium sulfate fertilizer as an organic mulch fire retardant. J. Arboric. 22:279-80.

Levesque, J. 2001. Lessons Learned Communication: Improperly Discarded Cigarettes Start Fires. Brookhaven National Laboratory. https://sbms.bnl.gov/l172/172d131.htm.

Miyanishi, K. 2001. Duff consumption, pp. 437-476. . In Johnson, E.A., and K. Miyanishi (Eds.). Forest Fires: Behavior and Ecological Effects. Academic Press, New York, NY.

Mulch Fire Standard Operating Procedure. 2002. University of Maryland Environmental Health and Safety. www.ehs.umaryland.edu/firesafety/MulchfireSOP.cfm (accessed 9/22/03).

Narciso, D. 1997. Families lose homes to apartment blaze. Columbus Dispatch, May 9, p C5.

Playground Fires Tied to Cigarettes. 1997. September 11. Columbus Dispatch, Sept. 11, p B3.
Relf, D. 1997. Organic Mulches. Virginia Cooperative Extension. $3 \mathrm{pp}$.

Rose, M., and E. Smith. 1996, Mulching Landscape Plants. Ohio State University Extension, Fact Sheet HYG-1093$96.5 \mathrm{pp}$.

Sternberg, R. 1997.Dublin Scioto to open after two bad air days. Columbus Dispatch, Oct. 8, p C7.

Sydnor, T. D. 1994. Selecting and planting trees. Ohio State University Extension Bulletin \#845. Columbus, OH. 20 pp.

Weather Records for Wooster, Ohio. 2002. The Ohio State University Ohio Agriculture Research and Development Center. www.oardc.ohio-state.edu/centernet/stations/ wohome.html (accessed 9/22/03).

Williams, D. 1996. Mulches for the Landscape, Alabama Cooperative Extension Service. 3 pp.

${ }^{1 *}$ Assistant Professor of Horticultural Industries Technologies Agricultural Technical Institute

The Ohio State University

1328 Dover Road

Wooster, OH 44691, U.S.

${ }^{2}$ Professor of Urban Forestry

School of Natural Resources

The Ohio State University

2021 Coffey Road

Columbus, OH 43210, U.S.

${ }^{3}$ Senior Statistician

Computing and Statistical Services

Ohio Agricultural and Research and Development Center

The Ohio State University

Wooster, OH 44691,U.S. 
Résumé. La facilité d'ignition de 13 paillis habituellement utilisés dans les aménagements paysagers a été évaluée. Les paillis ont différents degrés potentiels d'ignition basés sur plusieurs facteurs incluant le temps d'exposition à la chaleur et la source d'ignition. Certains matériaux s'allument plus fréquemment lorsqu'ils sont exposés à une torche au propane allumée durant 15 secondes. Les matériaux dont l'ignition est la plus facile vers ceux la plus difficile sont les résidus de caoutchouc, la fibre de pin, la paille d'avoine, l'écorce déchiquetée de bois durs, l'écorce déchiquetée de cyprès, les palettes recyclées, 2,5 à $5 \mathrm{~cm}$ d'écorce grossière de pin, 1,3 à 2,5 cm d'écorce grossière de pin, l'écorce de pin déchiquetée, les écailles de noix de coco, le compost de déchets végétaux, le gazon sec, et les cailloux de briques. Ce n'était pas tous les paillis organiques qui avaient une ignition instantanée, pas plus que les paillis inorganiques étaient tous uniformément résistants à l'ignition. Les résultats de cette recherche démontrent qu'il y a des différences définies dans la facilité à l'ignition entre les divers paillis communément employés. Les résultats démontrent que les paysagistes n'ont pas à recourir uniquement aux matériaux inorganiques tels que les cailloux de brique et le gravier comme paillis résistants à l'ignition. Lors de l'ignition avec une torche au propane, un matériau inorganique, le résidu de caoutchouc, s'est allumé de manière appréciable et de plus s'est avéré difficile à éteindre. Inversement, il y a des matériaux qui sont non propices à s'allumer, et il y a des pratiques d'entretien qui permettent de prévenir ou de réduire les risques d'ignition.

Zusammenfassung. Hier wurde das

Selbstentzündungspotential von 13 häufig verwendeten Mulchmaterialien bewertet. Mulche haben ein unterschiedliches Potential zur Selbstentzündung, die auf verschiedenen Faktoren, einschließlich der Dauer der Sonnenexposition und der Zündquelle basiert. Einige Materialien entzünden sich häufiger, wenn sie über $15 \mathrm{sec}$. einer offenen Propanflamme ausgesetzt sind. Die Reihenfolge von meist bis wenig entzündbar beträgt: gemahlenes Gummi, Kiefernnadeln, Weizenstroh, Hartholzrinde, Kakaoschalen, Kompost, Schilfsoden und Ziegelbruch. Nicht alle organischen Mulche entzünden sich sofort, noch bestand bei ihnen eine ähnliche Zündungshemmung. Die Ergebnisse zeigen, dass Landschaftsgärtner sich nicht zurückhalten müssen beim Einsatz von organischen Mulchen und auf nichtorganische Mulche wie Ziegelbruch und Split ausweichen müssen. Unter Propanzündung konnte ein nichtorganischer Mulch, gemahlendes Gummi entzündet werden und es war schwierig wieder zu löschen. Auf der Gegenseite gibt es organische Mulche, die schwer entzündbar sind und es gibt Erhaltungsmaßnahmen, welche die Gefahr der Selbstentzündung reduzieren.

Resumen. Se evaluó la facilidad de ignición de trece mulches comúnmente utilizados en paisajes. Los mulches tienen diferentes potenciales de ignición con base en varios factores incluyendo la duración de exposición al calor y la fuente de ignición. Algunos materiales de mayor ignición fueron expuestos a una llama de propano por quince segundos. Los materiales de ignición más fácil fueron: paja de pino, paja de encino, corteza en tiras de maderas duras, corteza en tiras de ciprés, paletas recicladas, trozos de corteza de pino de 2.5 a $5 \mathrm{~cm}$, trozos de corteza de pino de 1.3 a $2.5 \mathrm{~cm}$, corteza de pino desmenuzada, cáscaras de cacao, compost de desperdicios de jardinería, pasto seco y trozos de tabique. No todos los mulches orgánicos quemaron fácilmente, ni tampoco los inorgánicos resistieron uniformemente. Los resultados de esta investigación muestran que hay diferencias claras en la facilidad de ignición entre los mulches comúnmente utilizados. Los resultados demuestran que los paisajistas no tienen que recurrir a utilizar materiales inorgánicos tales como tabique y grava. Bajo la llama de propano, un material inorgánico ardió consistentemente y fue difícil de extinguir. Inversamente, hay materiales orgánicos que no arden fácilmente. 